\title{
Omnibus Law: The Opportunities and Challenges of Simplifying Legal Product
}

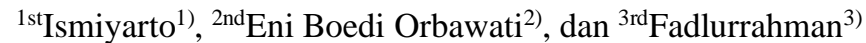 \\ \{E-mail: anto200708@gmail.com; ismiyarto@ipdn.ac.id, enybudiorbawati@gmail.com, \\ fadlurrahman@untidar.ac.id\} \\ 1) Lecture of Public Administration in Institut Pemerintahan Dalam Negeri Sumedang \\ ${ }^{2)}$ Lecture in Tidar University \\ 3) Lecture in Tidar University
}

\begin{abstract}
Omnibus law, which later in the form of legislation is expected to be simple, integrated, harmonious and not contradictory. This idea is a legal "fast road" effort to address Indonesia's "hyper legislation" and overlapping legislation. As for the urgency of omnibus law to create quality jobs; boost investment; and improve the welfare of workers. This research study method uses a qualitative descriptive approach, with data collection techniques through library documentation, newspapers and magazines. Omnibus Law is an early instrument that provides certainty and convenience for the business sector. That certainty and convenience is for not only large entrepreneurs, but also micro, small and medium enterprises (SMEs) therefore called Omnibus Law Cipta Kerja. Omnibus law is made one of them by considering the performance of investments in the past that have been colored by investment. The investment was triggered by overlapping regulations as well as sectorial egos between ministries, governors, regents or mayors. To that end, there is no other way that there should be innovation and a system that supports the government slashing all regulations that impede investment. Omnibus law is still required input from various parties and socialization in order to have similar perceptions considering omnibus law is a new policy in Indonesia.
\end{abstract}

Keywords: Omnibus Law; Innovation; Investment; Business Sector; and Legislation

\section{Introduction}

The idea of omnibus law formally presented by President Mr. Jokowi during a state speech after being sworn in as President of Indonesia Republic in 2019-2024. After the speech, the public space was filled with discoursers regarding omnibus law that is not familiar applied in the establishment of Indonesian legislation. The meaning of omnibus law adopted from the omnibus bill concept as follows: 1) A Single bill containing various distinct matters, drafted in this way to force the executive either to accept all the unrelated minor provisions or to veto the major provision; 2) A bill that deals with all proposals relating to a particular subject (Black's Law Dictionary, 2009). Simabura Charles - Compass March 9, 2020. Thus, omnibus law means establishing a single law aimed at changing or repealing the norms of some laws. Through omnibus law, it is expected that the law be simple, integrated, harmonious and not contradictory. This idea is a legal "fast road" effort to address Indonesia's "hyper legislation" and overlapping 
legislation. Is omnibus law the only way to organize and reduce obesity laws and regulations in Indonesia? Therefore, among other things, it is necessary to be institutionally directly accountable to the President.

Based on the study of Bappenas (2019), the causes of overregulation in Indonesia include the lack of synchronization and harmonization of regulatory formation in every ministry/and local government as well as weak policy and regulatory synergy. Monitoring and evaluation, and regulatory planning impact assessments are also not supported by in-depth policy analysis and are not based on actual necessity (evidence based approach); less dynamic regulation accommodates technological developments or socio-community needs.

Based on the stretch of the problem, initially the idea that emerged is institutional strengthening. The government will place the process of establishing regulations throughout ministries/institutions into a single centered legislation body and directly under the president. The agency is tasked with evaluating and simplifying old regulations and implementing the management formation of new regulations. The establishment of such an agency is important given the size of the president's power in the field of legislation. The president has authority in the establishment of laws, regulations, government regulations, presidential regulations. In addition, at the ministerial level that assists the president establish ministerial regulations, regulations of non-ministerial institutions even regulations of the director general or secretary general. As in February 2020, there are 1,687 laws, 4,570 government regulations, 2,049 presses, 14,815 ministerial regulations, 4,337 LPNK regulations (http://peraturan.go.id).

Omnibus Law or also can be called with omnibus bill is actually a method that is old enough. Omnibus law was first discussed and enacted in the United States in 1800s. In addition of USA, several other countries also apply this method, for example Ireland, England, Turkey, Canada, Vietnam, Australia, Singapore, and the Philippines. Omnibus law can be perceived as a simplification of the rules, currently being prepared by the Indonesian government. Its implementation is considered necessary and there are currently 8,451 central regulations and 15,965 local regulations that illustrate the complexity of regulation in the country. At least four omnibus laws are in 50 bills in Prolegnas Priorities 2020, namely the Bill on the State Capital, the Bill on Pharmaceuticals, the Bill on Work Creation, and the Bill on Taxation Provisions and Facilities for Economic Strengthening.

Omnibus Law Cipta Kerja there are at least eleven (11) clusters (80 laws /1,201 articles) affected namely simplification of licensing, investment requirements, employment, ease, empowerment, and protection of SMEs, ease of effort, research and innovation support, government administration, imposition of sanctions, land procurement, investment and government projects, as well as economic areas. According to Omnibus Law Cipta Kerja, changes in economic structure that are able to drive all sectors to drive economic growth reach $5.7 \%$ to $6 \%$ is expected to occur, namely through quality job creation, increased investment, and increased productivity. In the last six years, Indonesia's economic growth has reached only $5.17 \%$ in 2018. Meanwhile, in 2019 Indonesia's economic growth decreased to $5.02 \%$ after an increase in 2015 (4.88\%), 2016 (5.03\%), 2017 (5.07\%) and 2016 (5.17\%). Therefore, policy reformulation is necessary as a quick and precise response in response to the dynamics of global change. In addition, reformulation of the policy is necessary so that Indonesia does not fall into the trap of middle-income trap.

The benefits of Omnibus Law include as follows: eliminating overlap between laws and regulations; efficiency of the process of change or repeal of legislation; and eliminate sectorial egos. As a consequence of its application, the existing Law still remains in effect, unless some of the articles (legal materials) that have been replaced or declared in effect; The existing Law is no longer enforced, if the article (content material) that is replaced or declared 
in effect is the core or spirit of the law. Important points in the application of omnibus law are in line with the values contained in the constitution; in accordance with the laws and regulations governing the preparation of regulations; and continue to respect the authority of every institution involved in the regulations preparation.

The urgency of The Work-Created omnibus law, namely: the global economic slowdown; the threat of Indonesia's economic stagnation; Indonesia's competitiveness is not optimal; create quality jobs; boost investment; and improve the welfare of workers. If policy reformulation is not done, then: jobs move to other more competitive countries; the population that is not working will be higher; and Indonesia is stuck in a middle-income country. The advantages of the Omnibus law cipta kerja, namely: discussion is multispectral and incorporates many laws so that the necessary discussion time is faster. It is suitable to be applied in countries that have overlapping regulations, hyper regulation, and disharmony; the efficiency of the state budget in the process of drafting legislation can be attached; and create an instrument of ease of striving not only to benefit investors, both foreign and domestic, but also new-growth entrepreneurs.

\section{$2 \quad$ Methodology}

The authors used qualitative descriptive research methods and literature studies, conducting literature reviews based on the data required as primary and secondary materials of this writing. This research describes the problems that will be raised and then interpreted based on the theories used in this study. Descriptive research presents a detailed illustration of a particular state and situation, social order, or related. Data collection was carried out by collecting various written sources, such as journals, the internet, books, newspapers, and magazines used to decide policies were descriptive. The results of literature are the dominant source of the formation thought and interim conclusions (Silalahi, U. 2010: 27). Data analysis was carried out interactively, data reduction, data display, and conclusion drawing.

This topic of baptism is related to the opportunity, challenges and simplification of omnibus law. Omnibus Law, derived from Latin, means "for everything", which in law is defined as the need for a single document covering together a diverse combination of subjects on the basis of several criteria (Gunter, 2012 Kompas 27 November 2019). Literally, the word omnibus comes from the Latin Omnis, which means a lot and is often associated with a literary work that combines various genres, or the world of film depicting a film made from a collection of short films. In the Black Law Dictionary Ninth Edition from Bryan A. Garner is mentioned omnibus: relating to or dealing with numerous objects or items at once; including many things or having various purposes. Adjusting to that definition if it is in context with the law, it can be interpreted as the completion of various settings of a particular policy, set out in various laws and regulations, into one umbrella law.

As for the law, the word omnibus is usually juxtaposed with the word law or bill, which means a rule made, based on the compilation of several rules with different substances and levels. According to Audrey O" Brien (2009), omnibus law is a bill that covers more than one aspect combined into one law. As for Barbara Sinclair (2012), the omnibus bill was a complex regulatory process and the settlement takes a long time because it contains a lot of material even though the subject, issue, and program are not always related. 
Therefore, it can be said that omnibus law is a method or concept of making legislation that combines several rules whose substance of arrangement is different, into a large regulation that serves as an umbrella act. When the regulation was enacted, it had the effect of repealing some rules of the merger resulting from the merger and the subsequent substance was declared not applicable, either partially or in its entirety. This era requires another breakthrough, namely the need for omnibus law. Although Indonesia adheres to the civil law system, while omnibus law is born out of the tradition of the common law legal system, but in the world of digital ecosystem and global governance, it does not make it any way Indonesia breaks through this boundary space. Philippines have begun reforming the law in the context of investment by publishing The Omnibus Investment Code. Furthermore, Vietnam learned the techniques of making omnibus law, as part of its regulatory reforms.

Indonesia has also begun designing omnibus laws that will reportedly be issued, but there are still concerns this will conflict with ACT No. 12 in 2011 on the Establishment of Legislation. This condition will certainly be an interesting study of legal experts, on how to make omnibus law clear, adhere to the hierarchy rules, and guarantee the certainty law (Source: Paul https://business-law.binus.ac.id/2019/10/03/memahami-gagasan-omnibus-law/). The results of descriptive methods and literature studies related to omnibus law which are opportunities and challenges that are legal products to simplify and facilitate, then the authors can find 3 (three) theories to review and analyze them, namely:

Opportunities, according to Fachry Ali [10] mentioned that the chances of omnibus law the following influence success: a) this omnibus law could be the country's creative breakthrough in solving the scarcity of domestic capital supply. It can be called a vehicle for the creation of the so-called Dorodjatun Kuntjara Jakti in his dissertation entitled "The Political Economy of Development (1981), as a big push to eliminate giant barriers to economic development. This is important because today's structure and legal system can only bring in small-scale capital; b) The democratic system instead gives the advantages of omnibus law, this happens because the country that originally acted as the initiator, the success of the legislative process is a collective political agreement at the national level. Therefore, to make it collective property, openness about conceptual and practical reasons becomes much more important than just the preparation. With openness, not only does it eliminate the presumption of "era punters", but also the increasing participation of the nation's children to maintain its success; and c) Basically the solidity of the country's wealth has been formed since the late 1950's and early 1960's namely State-Owned Enterprises. With the establishment of the Ministry of State-Owned Enterprises in 1998, solidity has become more functional in creating or adding state-owned enterprises. While still accommodating foreign capital, omnibus law should take into account proportionally the position of State-Owned Enterprises as available capital actors, even if it is a domestic force.

Challenges, Agolla and Van Lill (2013:165) mentioned that public sector innovation today is known as a vital factor in addressing the challenges of globalization and demographic change while maintaining the quality of public sector services provided to the community. The growing demands of society and the environment are encouraging the public sector continue to innovate and finding new things that can keep pace with those demands. To change that perception is emphasized by the public sector that has innovation, exploration, as well as experimentation rather than stability, narrowing, or simply exploitation of existing knowledge (Choi and Chandler, 2015:1).

In addition, Stephen Harries (2012:26-27) conveyed several trends that led to a strong push to continue innovation in the public sector, namely: 1) Continued increasing public demand and expectations for better public services especially in areas that have a direct impact on society, such as health, education, and welfare. 2) Demographic changes in society; 3) 
Resources that remain the same over time even continue to decline, but are accompanied by increasing demand for public services; and 4) The need for professionalization of politicians and reevaluation of political roles[2].

Innovation as a process of emerging valuable ideas that transform into a new form to be a plus for organizations, employees, and stakeholders. In addition, innovation is considered to play a role in various aspects of people's lives, for example in creating new jobs, investment opportunities, solving social problems, creating higher income levels up to curing disease [1].

Simplifying Legal Product, J.A. Schumpeter described the consensus as creative destruction in order to improve the situation to get out of economic hardship. That is why crises usually spawn a variety of innovations and big changes. In times of crisis, there are not many policy options so there is almost no resistance to a major overhaul. In the eyes of labor activists, the Work Creation Bill is judged more accommodating to the interests of employers and harming workers. Omnibus Law is said to have been infiltrated by darker passengers with agendas of interests entered in various chapters. On the other hand, resistance to the Labor Bill also has the potential to be a vehicle for anti-government era punters.

In a democracy, policy has always been a battle of various interest groups. If not navigated properly, it could potentially pose a political risk. It takes a compromise between the parties so that there is the best solution for the future of the nation. The Work Creation Bill is often reduced only from the employment side regardless of the full context. The Labor Bill consists of 11 clusters of issues, ranging from simplification of licensing to the arrangement of economic areas. Employment is only one of them; there are 79 laws and 1,203 articles affected by this omnibus law.

Judging by the legislation scale, the focus of the Work Copyright Bill is the simplification of licensing that exists in 52 laws with 1,054 articles. The remaining 158 chapters are in 10 clusters of other issues. Employment issues have only 3 laws and 63 articles. Therefore, it is not true that employment problems were sacrificed in order to increase investment (Prasetyantoko - Kompas, 25 February 2020).

\section{$3 \quad$ Finding and Discussion}

Omnibus Law, especially the Work Copyright Bill has the potential to face lengthy debate, this is related to a number of employment articles, therefore compromise is required, both in process and in substance, so that the big goals are not suffered by debate without a solution. In many countries, omnibus law is usually done to make the economic structure more flexible, to adapt external changes.

Therefore in this discussion, in accordance with the topics and theories that have been presented in the above methods, namely related opportunities, challenges and simplifying legal products. To complement the understanding is also discussed the interconnectedness of omnibus law with the sector, the role of the center and the region in omnibus law as well as the need for socialization and input on omnibus law so that its implementation can be properly implemented and ultimately omnibus law can be beneficial for all parties. 


\subsection{Opportunities}

With regard to legal politics, policy method choices are also interesting to note. Simply put, this omnibus law method does have several advantages to be able to quickly spruce up and harmonize overlapping and irregular laws, Indeed there is no uniformity of the term in the practice of its use. The practice generally explains, omnibus law is used for some more similar clusters, for example with regard to the implementation of budget implementation (practices in Canada and US) although there are indeed practices that are too broad and large (Ireland). Widespread practice has always received strong criticism. Especially with the Work Copyright Bill that combines 11 clusters that have a pattern and a legal paradigm that is not uniform. When combined in one uniform concept, it is very likely to be a problem.

Omnibus Law Cipta Kerja is an initial instrument that provides certainty and convenience for the business sector. Certainty and convenience is not only for large entrepreneurs, but also for also micro, small, and medium enterprises [9]. Omnibus law is made one of them by considering the performance of investments in the past that have been colored by investment worth IDR. 708 trillion. The investment was triggered by overlapping regulations as well as sectorial egos between ministries, governors, regents or mayors. In addition, there are ghost games with a tinge and no wearing a necktie. To that end, there is no other way that there should be a system that supports the government to slash all regulations that impede investment.

\subsection{Challenges}

The lack of flexibility of the central government and accompanied by the move to create the Presidential Legislation as an instrument of rationing flexibility in turn will place the Presidential Legislation as an implementing regulation with powers that match the law, can be even stronger.

With such a position, the power of Presidential Legislation will increase and will exceed the power of the legislation of the House of Representatives, namely: 1) In article 20 paragraph (2) of the 1945 Constitution is regulated, the President has half the power of legislation. Half the power to form a law owned by the President is as strong as the other half of power held by the House of Representatives. With equally powerful powers, the law should not be restricted to regulating only things are general and the rest are left to government regulations. The law must govern in more detail so that the opportunities for abuse by the government can be reduced; 2) When the content material to be regulated in the law is further simplified and the rest is delegated to government regulations, what happens is the addition of the power of the President's legislation. This will have consequences for the wider power of legislation to the government and the more open the opportunity of misapplication.

On February 12, 2020, the Government submitted the Cipta Kerja Bill to the House Representatives. There is good intention behind the drafting of the Cipta Kerja Bill, especially accelerating Indonesia's economic development; especially the improvement of the investment climate and the increase in capital flows. The main purpose of this bill is to provide a formal legal basis for economic transformation and clean up the complicated licensing sector. One interesting aspect of this bill is the arrangement of research and innovation. In essence, the central government can assign to Stated-Owned Enterprises to perform general benefit, research and development and innovation functions. This gives rise to optimism and spurs the spirit of research and innovation development in Indonesia. This gives rise to invitation in advancing economic development and devotion in general [13].

As for the aspects that the government should look out for to address innovation challenges related to factors affecting innovation (OECD, 2017:19-21), namely: 1) Procedures and regulations, public sector employees often understand procedures and regulations as 
limiting the ability to innovate. 2) Human resource management, their commitment and determination is to drive every stage of the innovation process; 3) The Budget, given the uncertainty inherent in innovation, investment may need to be more flexible as funding for daily activities. 4) Innovation organizations, the capacity of the public sector to innovate depends on the quality and effectiveness of institutional management that supports innovation. Surely, institutional innovation is expected to vary depending on culture and tradition, as well as the degree of autonomy of organizations and individuals. The trend to create public institutions either as new bodies or as separation from existing ministries seeks to strengthen innovation by giving institutions flexibility to set their work methods and regulations to carry out their mandates. Other opinions related to innovation as expressed by Nobel Economics (2018) laureate Paul M. Romer that innovation is the director of future economics.

Based on various opinions on innovation, developed countries and countries with high per capita income and competitive in global competition are countries whose economic strength is supported by the development of research and innovation. Indonesia should take lessons from this fact. Economic development that emphasizes extractive and consumptive dispositions that rest on the utilization of natural resources needs to be reviewed. Research and innovation-based economies are inspiring and prove to be the strength of countries that excel in global competition. Research and innovation are key factors in the transformation of sustainable economic development. Relevant laws are a solid legal foundation for this transformation.

Several notes need to be put forward in examining the formulation stipulated in the draft Work Bill, namely: 1) clarity on why research and innovation is needed and what the objectives of research and innovation activities are supported by the state and or relevant stakeholders; 2) there should be clarity on who is involved in state-backed research and innovation activities. Without certainty the arrangements about anyone involved in research and innovation activities can be assured that this activity will never be held properly and achieve optimal results; 3 ) it is necessary to be clear how the rights and obligations of stakeholders in research and innovation efforts. Without the certainty of the rights and obligations of the parties, research and innovation programs are difficult to obtain support and will not even be implemented optimally. 4) Clarity is needed about the mechanism stipulated in its implementation, how the parties' support for research and innovation activities is established; and 5) clarity of the role of relevant institutions such as universities, national research councils and other institutions relevant to this activity. Clarity on the role of institutions is critical to ensuring synergy among stakeholders, including how incentive policy schemes will be designed and implemented.

The next challenge, namely if Omnibus law Cipta Kerja, is implemented in Indonesia, is feared not in line with the Indonesian legal system that adheres to the civil law system because the concept of omnibus law is better known for its application in countries that adhere to the common law system. Together with the rapid nature of discussion and expanding many sectors, omnibus law is feared to sideline the guidelines for the establishment of democratic legislation. It allows the trimming of the authority of the House of Representatives as a democratic legislator; and the results of the law are susceptible to material testing because the sharia tends not to pay attention to the principle of prudence (Djokosoetono Researc Center) - Media Indonesia, February 16, 2020.

The challenge that is no less interesting is that in the middle of the deadline, the Labor Bill still holds many problems. A number of problematic chapters are found in some of these clusters. One of the most obvious is the issue of employment, which is supposed to balance the interests of workers and entrepreneurs instead of leaning towards the interests of employers. Indonesian Confederation of Trade Unions chair Said Iqbal said increased investment should be in line with labor protections. The problem is, the Labor Bill cuts some aspects and rights that 
have so far protected workers, both purchasing power and bargaining power in industrial relations patterns. "Massive investment without the protection of workers should not happen because it will raise social unrest" [6].

In a democratic country, not many leaders dare to make major changes when the situation is fine. Big changes risk subverting his power. In economics, there is a consensus, when the good situation comes up more bad policies; on the contrary, bad situations incentivize the birth of more good policies (Prasetyantoko, Kompas February 25, 2020).

\subsection{Simplifying Legal Product}

The Work Creation Bill is a simplification of regulations to realize the welfare of the people. It also provides environmental law enforcement certainty on the right corridors. The business world does not mean big private. People who receive social forests are also part of it; environmental law enforcement is clear and bright, not removed. Therefore, it is not true to say this bill ignores environmental principles and pro-big business people only. Quite the contrary, this bill strongly favors the welfare of the small people.

Through this bill, social forestry programs and TORA (Agrarian Land Object Reform) will run fast. SMEs (Micro, Small, and Medium Enterprises) that do activities around the forest will live without ignoring the principle of forest protection because legal sanctions for environmental destroyers remain. The government mentions, problems that hinder the business world, especially corruption, ineffective bureaucracy, excesses of funding, infrastructure, policy and regulatory certainty, wage increases, and rupiah exchange rates. On the other hand, economic growth that averaged 5 percent in the last five years inadequately absorbed 45.84 million people in the working workforce. Every year there are 2.24 million new workforces. Through the Work Creation Bill, the government wants to create an attractive investment climate by eliminating a number of blocking rules and harmonizing overlapping rules. There are 79 laws combed, involving 31 ministries and institutions, resulting in the Work Creation Bill.

The public understands the government's desire to pursue quality growth. Job creation through investment is expected to increase people's income. Through this bill, there is expected to be a technological transformation including plugging the digital-based economy. Another goal is to prevent Indonesia from entering the middle-income trap. Although understanding and supporting, the purpose of the establishment of the bill there is a number of public criticisms. The process of drafting the bill is considered non-participatory, although on the grounds that there is no noise in its drafting with the result of the bill not being formed. The systematics bill is also considered confusing and a number of articles give rise to multi interpretation. Some of the issues in the spotlight concern employment issues, central and regional relations, as well as the environment.

Seeing so many affected by the Labor Bill, the government and the House of Representatives are expected to listen carefully to the public's input, as well as discuss carefully and thoroughly. If necessary, the discussion deadline is extended from the target of 100 days. We want the resulting legislation to address the purpose of the drafting of the bill so that it provides inappropriate medicine in answering current and future challenges. The institutions produced by The Work Copyright Act will want to be able to maintain long-term economic sustainability. All remain in terms of creating social justice for all people. 


\subsection{The Relating of Omnibus Law and Sector - Omnibus Law and Agriculture}

According to the purpose, The Work Copyright Act removes regulations that are considered burdensome to the influx of investment. According to the Asian Development Bank (ADB), agricultural investment in Indonesia mostly comes from farmers' own groups, while the value of private investment is still very low. Total foreign investment is only 0.01 percent of total private investment for agriculture. One of the regulations that have been burdensome to agricultural investment and horticultural sub-sectors is ACT No. 13 in 2010 on horticulture, namely limiting the use of horticultural facilities from abroad and requiring the priority of facilities containing local components. In addition, foreign investors are also obliged to place funds in domestic banks as large as their capital holdings. This regulation certainly makes investors think twice about getting into the horticultural sub-sector.

In the Work Creation Bill, burdensome regulations are replaced with regulations that are friendlier to the influx of investment. To invite horticultural facilities from home and abroad, the government encourages investors to venture horticulture. Similar things are also found in the plantation and agriculture sectors in general. In addition to inviting foreign investors in, it also facilitates the licensing of businesses that previously had to go through convoluted layers of bureaucracy, from requesting the recommendation of the Minister of Agriculture then asking the Permission of the Minister of Trade. This process is simplified into one license from the central government. Likewise, the process of seed import and expenditure can be easier through licensing efforts. With Indonesia increasingly open to investment and foreign facilities, agriculture can utilize existing capital and technology to promote productivity and efficiency. This will support Indonesia's goal of becoming the world's food barn in 2045.

a. Omnibus Law and Foreign Worker

The Labor Creation Bill makes it easier for foreign workers to work in the country's startups. The regulation of the broom is feared to narrow employment opportunities for the domestic workforce. Every employer that employs foreign workers must have a ratification of the central government's plan for the use of foreign labor. However, this obligation does not apply to a number of labor categories, such as start-ups or start-ups [6].

If Indonesian human resources have not met the needs, both in terms of quality and quantity, training become the solution. This training can be the responsibility of universities, vocational institutions, or training institutions. Executive Director of Indonesia Information and Communication Technology Institute Heru Sutadi argues that the ease of the facility has a negative impact, namely beings employment opportunities for the domestic workforce. For digital start-ups from abroad, it proposes priorities for the use of domestic labor.

Separately, the founder of the Institute for Social, Economic, and Digital (IDEI), Sri Adiningsih assessed the Work Copyright Bill had not fully facilitated the digital transformation process. In fact, the automation process in the business world is prone to causing shocks to the absorption of the workforce. The Creative Economy Agency abbreviated as (Bekraf) shows that the needs of the digital workforce reach 600,000 people every year, as new start-ups are not all that needs met.

b. Omnibus Law and Employments

The main issue highlighted in the Work Creation Bill is the licensing issue, which has implications for institutional support for the economy. The issue of power has always been a sensitive issue, even political. There are several things that are being sued, namely changes to minimum wage regulations, severance obligations in termination of employment, expansion of 
the definition of outsourcing, and the opening of access to foreign workers. The purpose of Cipta Kerja omnibus law is to transform the economic structure through increased productivity, investment and the opening of new jobs. It is expected that Indonesia can become a developed country with an average per capita income rate of 27 million per month by 2045. In other words, the bill is designed to escape the pitfalls of middle-income countries.

There are several conditions for us to get out of this trap: 1) economic growth is in the range of $5.7-6$ percent so that it will create 2.7 million -3 million new jobs per year. 2) an increase in investment of 6.6 - 7 percent resulting in an increase in per capita income and consumption; and 3) productivity improvements that will also be followed by increased incomes. The Work Creation Bill is projected to be one of the important levers for the improvement of productivity and competitiveness of the domestic economy.

One example of this is that employers may have terminations, but have a responsibility to ensure the workforce gets a new job through a training program after termination. This concept can be adopted by compiling various social policies of the government with the participation of private parties. The principle of flexibility has actually been embraced in the Omnibus Law Cipta Kerja through the Job Loss Guarantee program through three options, namely cash demands, vocational training, and work placement. This program can be integrated with other government programs, such as Karatu Indonesia Kerja. The Labor Bill requires multiparty consensus, especially governments, employers, and working groups. On the one hand, we need greater leeway, but on the other hand, it needs better job security. Do not let darker passengers from both sides roam to sabotage the national interest (Prasetyantoko, Kompas 25 February 2020).

\section{c. Omnibus law and Energy Mineral Resurce}

At first, the licensing issue was complicated, convoluted and there was no certainty when it was completed. The government believes such conditions are bad for Indonesia's investment climate. Then prepared a Work Copyright Bill that is expected to be the solution. Is there a guarantee? [9]. In the energy and mineral resources sectors, there are four laws included in the revised Work Creation Bill. The four laws are on oil and gas, mineral and coal mining, heat, and electricity.

Most of the revisions to the four laws are about withdrawing licensing authority from the local government to the center. In effect, there is a distrust of the central government towards the local government for investment affairs in their respective regions. News of complicated licensing is convoluted, overlapping administrations, and bribery or corruptions for the affair often color the news. So is the news of environmental damage or the destruction of conservation areas. For example in the mining sector since licensing was granted to the district and city governments, the number of Mining Business Licenses abbreviated as (IUP) jumped dramatically to more than 10,000 permits. There are symptoms of a permit sale by the head of the local area. The permit sale was also related to the selection of regional heads. Because of the fast-paced nature of the sale, the standard governance principles were ignored. As a result, permits overlap, scrutiny in the field is weak, even down to the practice of bribery for the issue of such permits.

In the country's financial sector, many IUP holders do not deposit taxes and royalties. Corruption Eradication Commission coordination and supervision results in 2016 mentioned from 10,000 more IUP; 90 percent do not fund reclamation guarantees; 70 percent pay no taxes and royalties; and 36 percent do not have a Taxpayer Identification Number known as NPWP. These Liabilities are amounting to IDR. 4 trillion (Kompas, August 1, 2017). Not to mention in the oil and gas sector, although since the beginning more controlled by the central government, 
there is still business in the region. Permits must be taken care of from across ministries and institutions, in centers and regions, more than 300 types of permits. It is not clear when each permit will be completed. For example, Masela block on the sea off Maluku found in 1998, the management decision only came out in 2016. The question is whether once all authority is drawn to the center then the problem can be resolved? No one knows yet and guarantees.

Citing the statement of the Head of Geology and Groundwater in Banten Provincial Government's Ministry of Energy and Mineral Resources Office in a discussion in Jakarta, the existing laws are actually quite good. Only the implementation is problematic. The implementation is clearly concerning about its human resource capacity. What does good law mean, but it is not implemented? In addition to the quality, the limited number of resources also adds to the problem.

The withdrawal of all authority to the center does not guarantee that everything will be okay. Some argue that the quality of resources at the center is better. The reality is one hundred percent incorrect. In fact, a corruption-involving person in the central government from across agencies and ministries seems to have never subsided. In addition, despite all the diametric licensing to the center, investors may not permit or simply "excuse" the local government. This is related to the utilization of local labor and local content. Therefore, once it is legal to become law, its implementation must be consistent. The government is responsible for providing sufficient, quality, and committed resources that natural resources to the great wonder of the people, not the prosperity of themselves and their groups.

\subsection{Central and Regional Roles in Omnibus Law}

The government will formulate environmental permit standards and analysis of environmental impacts. In the Working Copyright Bill will be regulated the homogenization of the norms, procedures and criteria of environmental permits and Amdahl's. Environmental and Amdahl permits (analysis of environmental impacts) are not withdrawn to central investors. The center will instead create standard standards so that the process is not repeated (Minister of Economic Affairs). Later, the filing of Amdahl for low-risk businesses simply by stating approval will meet the requirements. Therefore, businesses do not have to apply repeatedly if the industrial area is developed according to the provisions. The mandatory business was originally regulated with nine criteria in Law No. 32 of 2009 on Environmental Protection and Management as a criterion in the Work Copyright Bill [5].

New regulations on environmental issues are always sensitive, therefore the government will formulate carefully and in accordance with laws such as for steel mills, textile waste, and palm oil. Standard formulations of environmental and Amdahl permits are required to create certainty. The problem is that inter-industry standards are not harmonious; standards must be standardized and clarified. Future granting of Amdahl permits should be more selective. Permission is granted based on various considerations, especially risks. Amdahl permits are only required for high-risk businesses, such as industries with hazardous raw materials, for industries with low environmental risks, permits are feared to be harmful. The Entrepreneurs that sectors are not only stylish but also are obliged to make Amdahl that cost hundreds of millions of rupiah severely there is no monitoring. From that fact, it is more important to monitor, evaluate over time.

\subsection{Omnibus Law Socialization and Input}

The relevant ministries will implement the socialization of The Work Creation Bill to the community; the Ministry of Economy prepares a plan around the region to commercialize and related institutions of this bill. The team will explain in detail to the local government about 
the intent and purpose as well as the formulation of the articles in this bill. Furthermore, the local government is tasked with commercializing the regulation to the community. The government will also invite various civil society groups and academics to discuss the articles that the public should understand that this bill was created to encourage the creation of jobs.

The government's openness to the input of various parties to the Labor Bill is an opportunity to provide constructive input. President Joko Widodo said the government was open to the input of various parties. Discussion of the bill will involve various parties, and this bill is a government proposal. The government reasoned that the level of ease of investing in Indonesia is inferior to other countries, even with ASEAN, because of too much regulation. There are 43,511 rules from central to regional governing investment [5].

\section{CONCLUSION}

a. The advantages of omnibus law can quickly spruce up and harmonize overlapping and irregular laws.

b. Omnibus Law Cipta Kerja is an initial instrument that provides certainty and convenience for the business sector, not only for large entrepreneurs, but also for also micro, small, and medium enterprises.

c. One of the interesting aspects of this bill is the arrangement of research and innovation. In essence, the central government can assign to State-Owned Enterprises is gives rise to optimism and spurs the spirit of research and innovation development in Indonesia.

d. Omnibus law Cipta Kerja, when applied in Indonesia there are concerns not in line with the Indonesian legal system that adheres to the civil law system because the concept of omnibus law is better known for its application in countries that adhere to common law system.

e. The Work Copyright Bill still holds many problems, a number of problematic articles found in some of the cluster. One of the most obvious is the issue of employment, which is supposed to balance the interests of workers and entrepreneurs instead of leaning towards the interests of employers.

f. The Labor Bill slashes a number of aspects and rights that have so far protected workers, both purchasing power and bargaining power in industrial relations patterns.

g. The Work Copyright Bill is a regulatory simplification to realize the welfare of the people. It also provides environmental law enforcement certainty on the right corridors.

h. Through the Work Copyright Bill, the government wants to create an attractive investment climate by eliminating a number of blocking rules and harmonizing overlapping rules.

i. The interconnectedness of omnibus law with other sectors, for example with the agricultural sector, will be more open Indonesia to investment and foreign facilities, agriculture can utilize existing capital and technology to encourage productivity and efficiency.

j. The government will invite various civil society groups and academics to discuss the articles that should be understood by the public that this bill was created to encourage the creation of jobs. The Government is open to the input of various parties to the Work Creation Bill. 


\section{REFERENCES}

[1] Agolla, Joseph E. dan J.B. Van Lill, 2013, “Public Sector Innovation Drivers: A Process Model" J. Soc Sci;

[2] Harries, Stephen, 2012, Records Management and Knowledge Mobilisation A Handbook for Regulation, Innovation and Transformation, Oxford: Chandos Publishing;

[3] OECD, 2017, Fostering Innovation in the Public Sector, Paris: OECD Publishing;

[4] Dilema dalam RUU Cipta Kerja - A. Prasetyantoko - Kompas 15 Februari 2020;

[5] Pusat dan Daerah Berbagi Peran - Kompas 22 Februari 2020;

[6] Ruang bagi Pekerja Asing Semakin Lebar - Kompas 27 Februari 2020;

[7] Omnibus Law dan Pertanian - Felippa Amanta - Kompas 2 Maret 2020;

[8] Obesitas PP Omnibus Law - Khairul Fahmi - Kompas 3 Maret 2020;

[9] RUU Cipta Kerja Atasi Investasi Mangkrak; RUU Cipta Kerja - Labirin Pusat \& Daerah - Kompas 6 Maret 2020;

[10] Omnibus Law, BUMN, Negara - Rachry Ali - Kompas 7 Maret 2020;

[11] Overdelegasi Kuasa Legislasi Presiden - Charles Simabura - Kompas 9 Maret 2020;

[12] Politik Hukum RUU Cipta Kerja - Zainal Arifin Mochtar - Kompas 9 Maret 2020;

[13] Riset dan Inovasi dalam RUU Cipta Kerja - Sigit Riyanto - Kompas 23 Maret 2020; 